\title{
Functional and spatial model of university complexes transformation into structural elements of Samara-Togliatti agglomeration innovative development cluster
}

\author{
Elena Akhmedova ${ }^{1}$, Anna Zhogoleva ${ }^{2, *}$ \\ ${ }^{1}$ Samara State Technical University, Architecture and Construction Academy, 443001, Samara, \\ Molodogvardeyskaya Street 194, Russia \\ ${ }^{2}$ Samara State Technical University, Architecture and Construction Academy, 443001, Samara, \\ Molodogvardeyskaya Street 194, Russia
}

\begin{abstract}
The article explores the actual cluster approach to the planning of agglomeration territories sustainable development. The authors in their research investigate the notion of sustainable territorial development as the development of urban planning structures basing on the frame of the educational, industrial, financial and economic information exchange nets built in the structure of the agglomeration. Such a subject-oriented frame must not be formed as rigid, constant, and static; its flexibility and variability, complementarity and interchangeability of its knots and elements allow the urban planning system sustaining and developing itself. The conclusion is drawn in the article that the urban planning development policy of Samara-Togliatti agglomeration (basing on cluster strategies) will enable the universities of the region (including the flagship university, national research university) to form the platform of innovative cluster infrastructure of the region and agglomeration. Key words: sustainable development, innovative clusters, Samara-Togliatti agglomeration, clustering, agglomeration, university complexes, industrial parks, flagship universities, national research universities.
\end{abstract}

\section{Introduction}

Within the strategy of sustainable urban planning development of agglomeration territories urban planners distinguish the following directions:

- the social and economic sustainability of urban planning education [1];

- the sustainable structure and planning development of the territory [2];

- the sustainable communication frame development of territories agglomeration (transport, pedestrian, business communications);

- the ecological balance of the territory, landscape and sustainable planting of trees and shrubs.

The contents of these directions broaden the notion of territorial sustainable

\footnotetext{
* Corresponding author: annazhogoleva@yandex.ru
} 
development; dictate various approaches to planning and architectural and urban planning projecting of agglomeration territories.

The cluster approach to the planning of agglomeration territories sustainable development bases both on the development of planning and transport communications and on the frame of the industrial, financial, economic, and human resources interactions, networks of business collaboration built in the agglomeration structure. In its turn the intersettlement labour market is being formed; suburban and countryside building (production, business function, social objects, lodging, and rest) is being activated; complex planning development of agglomeration territories is happening on the basis of this frame [4]. The type of spacial cluster structure - i.e. net, knot, discreet, compact, linear - determine the character of the urbanised territories agglomeration processes [5].

The character of the cluster structure, its branch specialisation can be different - in Samara Region enterprises of aerospace, automotive cluster function successfully, the organisation of pharmaceutical cluster is being planned. The important condition of innovative environment forming in cluster structures of our region is the creation of common information and activity space, organisation of effective means of information transfer, necessity of information exchange intensification and cooperation with the cluster enterprises. International experience of cluster structures management bases such strategies on the university science, research institutes and academic schools.

\section{Theory}

\subsection{Regional research}

In our region, where the system of higher education has stable, high indicators, the organisation of the innovative development cluster on the basis of universities is a difficult, but actual task for the development of the city, agglomeration and region, the solution of which is possible with the attraction of the whole row of participants: regional and city authorities, industry, large, small and middle size businesses.

25 educational institutions of higher education, including 16 state ones, function in Samara Region. 111000 students and more than 500 postgraduate and doctorate students study there, more than 25000 bachelors and masters graduate from the regional universities annually. The educational process in universities is provided by about 11000 lecturers, more than 5000 candidate degrees and more or almost 1300 doctoral degrees are among them. The biggest number of students in Russia is located in Moscow and St. Petersburg; these are the most student cities in Russia. Samara takes the 4th place in the rankings of student cities in Russia. On every 10000 dwellers of Samara Region there are approximately 500 students averagely, that is higher than the average rankings in Russia, and it is comparable with similar indicators of the most developed countries in the world [6]. All universities and their branches are placed in the structure of Samara-Togliatti agglomeration, its cities-centres: Samara, Togliatti, Kinel, and Syzran.

Innovative processes in the cluster base on the coordination of several participants of different competence and qualification, being implemented by the method of exchange: no participant of the innovative process possesses enough information and is not able to realise the whole technological cycle of the cluster on its own. Different objects of the cluster infrastructure are organised under the different technological stages of cluster strategies [7].

On the basis of regional industrial parks the processes are being organised in the competences "regional authorities - investors - industry", connected with the launch of new small, middle and large industrial enterprises. 
On the basis of business incubators the processes of competence display are being organised in "relations university - production" (business consultants), the possibility to "transfer" information and "demonstrate" the results of activity is foreseen. Offices and technology transfer centres implement the analysis of research being conducted at the university with the aim of search of business-partners and state programmes, where the implementation of the given research work is possible. Small innovative enterprises test new technologies and launch them in production.

On the basis of co-working centres by the competences of universities, business, youth social organisations the conditions for extra-curricular activity of students are being created, their engagement in professional, social activity, for the development of freelance and small business in the non-productive sphere, i.e. the sphere of service, consulting, creative technologies, etc. (fig.1) [8].

On the basis of regional and city project centres the processes of management, urban, agglomeration planning, regional development, research, projecting in the competences "university - regional, city authorities - public" are being organised (fig.1) [8].

On the basis of educational centres due to the competences of universities and research organisations open educational programmes for a wide circle of audience, professional development courses, additional to the higher education, joint research with the external partners, consultative services of own and invited specialists are being organised.

\subsection{The methods of organisation, intensification and information exchange in innovative development cluster structure}

Today the academic and educational potential of our region universities is rather high, and besides the organisations of the first information process (directly research and educational activity), the development of the secondary information flow organisation methodology is being intensified. Their main directions:

- display of competence in the corresponding sphere, both on commercial and social basis (Legal Clinic of SSU, Inter-University Medical Centre), teaching computer literacy;

- creation of general access centres to information resources (Media Centre at SSAU), creation of common information bases, media centres, polygraphic centres;

- holding of inter-university conferences and Olympiads;

- supervision of research and innovative activity.

Herewith, the processes of interdisciplinary combination both inside separate universities and between the universities, search of information in the format of monitoring, inter-university information transfer (conference), demonstration (exhibitions, presentations) are not developed enough. Research activity of the universities is not limited by the inside research divisions, the interaction of universities and research institutes of Samara is being made in several directions.

Large industrial organisations (Central Assembly and Design Engineering Bureau "Progress") hold seminars and competitions for students, support programmes of partial payment of graduate and postgraduate students' education. Educational centres are being created on the basis of the universities, for instance, educational centres JSC "Volgaburmash", CJSC "Electroshield", CJSC "Samara Cable Company" in Samara State Technical University. The universities and enterprises make joint Research and Development Institutes - in 1998 on the basis of research and development laboratories of SSAU and Samara Metallurgy Plant Volga Branch of IMET was created [9].

Apart from commercial organisations the university partners can be social institutes. With participation of SSU the making of social expert reviews, social unions of Samara Region "Samara Regional Social Organisation "Historic Eco Cultural Association "Povolzhye" and Samara Social Organisation of Wheelchair People "Desnitsa" was being 
conducted. Currently, Samara Social Organisation of Wheelchair People "Desnitsa" and Department of Architecture of the regional flagship university SSTU have organised cooperation, joint courses, seminars; forums are being conducted with the aim of implementation in teaching architecture students the rules and norms of the urban environment availability for population groups with low mobility. Thus, the net of secondary information processes in the inter-university environment becomes more and more diverse and unites more and more participants.

The being formed regional net of Centres for Youth Intellectual Creativity (CYIC) must be mentioned. Currently, 4 CYICs, opened on the basis of SSAU, SamSMU, SSEU, TSU (3 in Samara, 1 in Togliatti), are working. All CYICs are equipped with everything necessary for the attraction of the students and youths to Robotics. Project "Formation of human resources potential for aerospace industry via the development of children and youths' technical creativity in the sphere of Robotics. R2D2-Samara" was launched in 2014. Currently, the "R2D2-Samara" project has 15 constant partners, which help to hold the events in Robotics. JSC Akvil, Oleg Deripaska Foundation Volnoe Delo, LEGO, Microsoft, CJSC Kaspersky Lab, JSC Webzavod, NGO Android Technics, JSC Camozzi Automation, OJSC ICl, etc. are among them.

The organisation and intensification of information exchange in the sphere of innovations can occur on the basis of the university infrastructure, including the federal, national research and flagship universities that have additional state support. Samara National Research University was created as a result of the merge of SSAU and SSU in Samara. As the result of reorganisation of two large Samara universities as well - Samara State Technical University (SSTU) and Samara State University of Architecture and Civil Engineering (SSUACE) - SSUACE was included into the flagship regional university SSTU. The support of the university on the state level - financing of the programme of the flagship university, including work with the talented youths and realisation of innovative projects - was received due to this.

In 2015 the joint library was created in Samara National Research University as a result of the merge of the libraries of SSAU and SSU. It became the largest university library in the region - its fund is approximately 2,3 million issues. In volume of the fund the library is smaller only than the Samara Region universal library, where 4,5 million documents are stored. The lecturers and students have access to the research works indexed by the largest international bases Web of Science and Scopus, journals of the publishing companies Elsevier, OSA, EBSCO, electronic library systems Ibooks, Urait, Rucont. Herewith, the access can be carried out not only from desktop computers, connected to the university local net, but from personal devices in hostels and via the unified Wi-Fi net, being active all over the campus [9].

In 2015 the Volunteer Centre for the 2018 FIFA World Cup in Russia was opened at Samara National Research University. The tasks of the Volunteer Centre include attraction, preliminary selection of candidates in volunteers and organisation of the training of volunteers not only from the university students, but for every one older than 18 [10].

The flagship university of Samara Region (SSTU) also serves as an efficient ground of the secondary information flows and competences development in competences "university - regional and city authorities - publicity", "university - culture". In October 2016 in Architecture and Construction Institute of SSTU the round table "Architecture of the flagship university: ideas, projects, possibilities" with the participation of Samara Mayor O. Fursov, Samara chief architect A. Samartsev, Samara Region deputy Minister of Construction of Samara Region Government A. Barannikov and others took place. XVI Festival of fashion and theatre costume "Volga seasons by Alexander Vasiliev", where young designers from 32 Russian cities presented new original collections, took place in Architecture and Construction Institute of SSTU in Samara on 14-16 October, 2016. On the 
basis of SSTU the selection ground of the all-Russia competition "UMNIK" is functioning. The Russian-French forum "Preservation and development of cities", etc. was held in the regional flagship university in September 2016.

\section{Experimental project. Functional and spatial model of university complexes transformation into structure "United cluster - Samara yard"}

On the basis of urban planning analysis of the innovative development cluster elements position on the territory of Samara the biggest concentration territory of possible cluster elements in the historic centre within the borders of the streets Molodogvardeyskaya, Galaktionovskaja, Vilonovskaja, Pervomaiskaya can be distinguished [11].

Participants: buildings of SSTU (Galaktionovskaja Street 141, Molodogvardeyskaya Street 133, etc.), Volga Business Institute (Galaktionovskaja Street 141), building of SSUACE (Molodogvardeyskaya Street 194), building of SSAU (Molodogvardeyskaya 151) morphological building of SSMU, Samara State Regional Academy of Najanova, building of Samara Scientific Centre of RAS, Volga Centre for Space Geoinformatics, Research and Production Enterprise Computer Technologies (Molodogvardeyskaya 151), Centre for Energy preservation and Certification of SSTU.

The main structure-forming frame of this territory is Molodogvardeyskaya Street, the arterial street of district status. Kuybyshev square, the Square of Glory, Samara square, squares, avenue along Polevaya Street, the presence of architectural ensembles, historic quarters and monuments make this street attractive for pedestrians and give it the opportunity to become the linear centre of this part of the city. The concentration of cultural, trade and service objects in different spheres, administrative objects contribute to it.

The programme of innovative technologies cluster development "United cluster Samara yard" in the historic centre of Samara. It is supposed that the territory will be saturated with the functions of servicing with the use of the united cluster model, i.e. concentration on one and the same territory of multiple organisations, rendering similar services. The main task is to create information field on the levels university - society, university - government.

On the university territory it is supposed to locate the centres with universal zones for holding lectures, presentations and listenings, isolated zones with the premises for holding negotiations, meetings, and working places with Internet access, café. Every centre is supposed to have its own specialisation. SSTU Centre for Architecture and Civil Engineering Institute (ACEI) provides professional information exchange between the researchers inside the university and external partners, workshops for creative, engineering, project and self-supporting activity of students and researchers. The location of free access zones for visitors for transfer and demonstration of the university artistic and technical experience, holding of listenings and discussions. The main task of the centre SSTU is the provision of technical experience and competent services transfer: project work with partners of the university, competent-centres of open access. It is necessary also to organise the processes of translation and demonstration of non-professional creative activity.

The third centre - techno-park SSEU - which renders competent services and provides gross leasable areas for entrepreneurs and researches. Centre SRC RAS is the zone of information exchange in the scientific sphere. On free zones it is supposed to place both gross leasable areas (office, co-working) and artistic centre of open access with workshops, exhibition spots. Along the streets, in the first floors of buildings it is possible to make both servicing functions (café, "anti-café", shops of consumable material) and mini-media- 
centres with Internet access, co-workings, artistic workshops and exhibitions, workshops of technical items repair, small consultative centres.

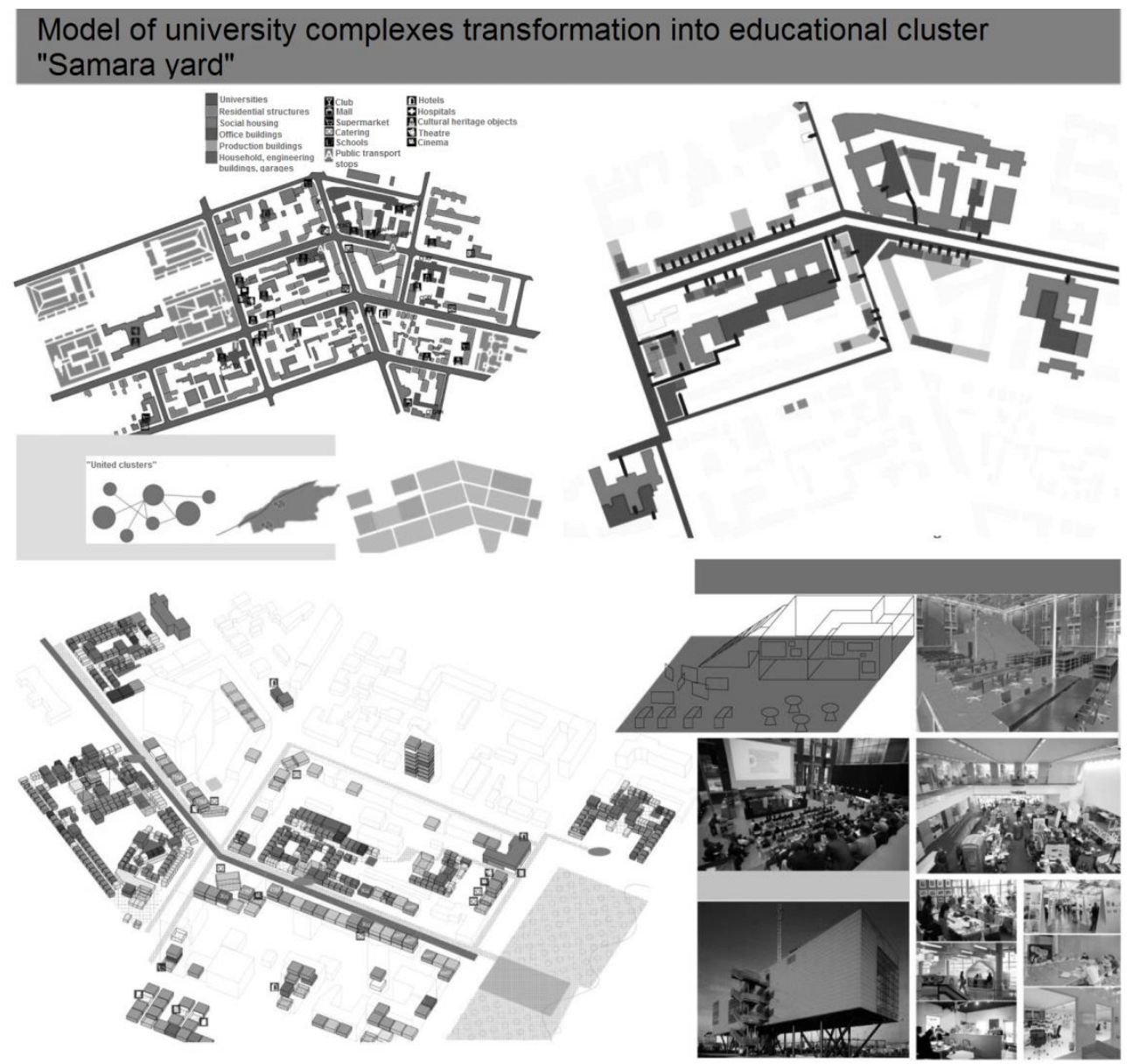

Fig.1. Model of university complexes transformation into educational cluster "Samara yard"

\section{Discussion}

Urban planning programme of the development of existing university campuses, interuniversity and joint city areas can support the realisation and successful development of all these strategies within the development of cluster strategies. Herewith, the realisation of these programmes can be not only a university undertaking, but the one of the agglomeration and regional importance, discussed and regarded in the new general plan of Samara, in the strategy of Samara Region development. In the programme of the development of the flagship university SSTU, developed till 2020, it is planned to project the congress-centre, in the structure of which conference-hall, co-working, show-room, exhibition centre, competence centre, engineering centre, media centre can be organised.

\section{Conclusion}

Samara National Research University, the flagship university of Samara Region SSTU due to their joint resources and competent urban planning policy of Samara-Togliatti 
agglomeration and Samara can be the platform for creation of objects of inter-university cluster infrastructure and formation of innovative educational environment with the purpose to grow the human capital and sustainable development of Samara-Togliatti agglomeration social and economic progress.

\section{References}

1. V. Andrievskaja, A. Jestrin, E. Akhmedova, T. Karakova, V. Shabanov. Strategicheskoe gorodskoe planirovanie (2001)

2. V. Ljubovnyj. Goroda Rossii: al'ternativy razvitija i upravlenija (2013)

3. E. Anoshkina, I. Leshhev. Problemy sovremennoj ekonomiki 4 (32) (2009)

4. URL: http://www.rusrev.org/content/review/default.asp? shmode=8\&ida=2169\&ids=162

5. E. Akhmedova, G. Proskurin. Vestnik Orenburg State University 4 (2007)

6. E. Akhmedova, G. Proskurin. Samarskij statisticheskij ezhegodnik, 17 (2016)

7. V. Tarasenko. Territorial'nye klastery: sem' instrumentov upravlenija (2015)

8. A.V. Zhogoleva, A.N. Teryagova, Nauchnoe obozrenie 9, 362-365 (2015)

9. URL: http://www.ssau.ru/news/12446-V-Samarskom-universitete-sozdaetsyaMolodezhnoe-informacionnoe-agentstvo/

10. URL: http://www.ssau.ru/news/13322-Stan-volonterom-Chempionata-mira-pofutbolu-FIFA-2018-v-Rossiisuptmsup/

11. A.V. Zhogoleva, E.A. Drachkova. Architectural and Urban Planning Transformation of University Campuses (2014). 